International Journal of Mechanical Engineering and Technology (IJMET)

Volume 11, Issue 12, December 2020, pp. 33-44, Article ID: IJMET_11_12_004

Available online at https://iaeme.com/Home/issue/IJMET?Volume $=11 \&$ Issue $=12$

ISSN Print: 0976-6340 and ISSN Online: 0976-6359

DOI: https://doi.org/10.34218/IJMET.11.12.2020.004

(C) IAEME Publication

Scope Database Indexed

\title{
VIBRATION EXPOSURE ASSESSMENT OF SAWMILLING OPERATIONS USING HAND- ARM-VIBRATION EXPOSURE ANALYSIS
}

\author{
Abiola Olufemi Ajayeoba* \\ Department of Mechanical Engineering, Ladoke Akintola University of Technology, \\ Ogbomoso, Nigeria. \\ Adewoye Alade Olanipekun \\ Department of Civil \& Environmental Engineering, \\ Bells University of Technology, Ota, Nigeria. \\ Oluwaseun Oluwagbemiga Ojo \\ Department of Mechanical Engineering, Adeleke University, Ede, Nigeria. \\ Oluremilekun Ropo Oyetunji \\ Department of Mechanical Engineering, Ladoke Akintola University of Technology, \\ Ogbomoso, Nigeria.

\section{Wasiu Adewale Raheem} \\ Department of Systems Engineering, University of Lagos, Lagos, Nigeria. \\ *Corresponding Author
}

\begin{abstract}
Sawmills are workshops where woods are turned into finished products through the use of industrial machines and sophisticated implements. However, sawmills workers become exposed to awkward working postures and vibration from the machines they work with every day, leading to Raynaud's disease and muscle damage. Therefore, this study investigated the effects of the sawmill-machine-generated vibrations on the musculoskeletal disorders of sawmill workers in the Southwestern part of Nigeria using hand-arm-vibration analysis. Sawmills that were fully functional in Osun, Oyo, Ondo, Ekiti, Lagos, and the Ogun States of the Southwestern part of Nigeria were used for this study. After reconnaissance visits, four sawmills operating at full capacities in two cities of each State (i.e. 2 sawmills per city) were eventually chosen and used for data collection, thereby making a total of 24 selected sawmills. Circular Machines (CMs), Planer Machines (PMs), and Band-saw Machines (BMs) which are the commonly used machines by sawmills were considered for analysis, while two machines each of CMs, PMs, and BMs were also selected in each sawmill,
\end{abstract}


making a total of forty-eight (48) machines each of CMs, PMs, and BMs. Vibration level data were collected in $\mathrm{m} / \mathrm{s}^{2}$ using Extech VB 450 vibration meter in triplicates, and the corresponding exposure time was obtained. The vibration acceleration magnitude and exposure time data were collected for six days (Monday to Saturday). The daily Exposure Action Value (EAV), Exposure Limit Value (ELV), and exposure points were then determined for each daily operations of the considered sawmilling machines.

The average Wood Vibration Acceleration Magnitude (WVAM) ranges in CMs and $P M s$ in each sawmill were $34.2-104.1 \mathrm{~m} / \mathrm{s}^{2}$ and $104.1-173.7 \mathrm{~m} / \mathrm{s}^{2}$, respectively, while the average Machine Vibration Acceleration Magnitude (MVAM) range in BMs in each sawmill was $10.7-48.0 \mathrm{~m} / \mathrm{s}^{2}$. Also, the minimum and maximum WVAMs in CMs and PMs and MVAMs in BMs in all sawmills were 32.2/106.7, 99.1/187, and $10.2 / 49.3 \mathrm{~m} / \mathrm{s}^{2}$, respectively.

The Analysis of Variance (ANOVA) results revealed that there are statistically significant differences in the WVAMs of CMs and PMs and MVAMs of BMs in all the six states. The vibration exposure analysis showed that none of the average values falls within the limit and action values, because the values were well above the exposure limit value of 400 points. The study concluded that the contributing factors responsible for the high values of the exposure analysis experienced by workers were obsolete machines, lack of proper working tools, worker's carelessness, and general negligence by workers.

Keywords: Exposure, Magnitude, Musculoskeletal Disorders, Sawmills, Vibrations.

Cite this Article: Abiola Olufemi Ajayeoba, Adewoye Alade Olanipekun, Oluwaseun Oluwagbemiga Ojo, Oluremilekun Ropo Oyetunji and Wasiu Adewale Raheem, Vibration Exposure Assessment of Sawmilling Operations using Hand-ARMVibration Exposure Analysis. International Journal of Mechanical Engineering and Technology. 11(12), 2020, pp. 33-44.

https://iaeme.com/Home/issue/IJMET?Volume $=11 \&$ Issue $=12$

\section{INTRODUCTION}

Griffin [1] stated that forests occupy four billion hectares of the earth's land surface and 3.5 billion $\mathrm{m}^{3}$ of their mature stock were removed from the forests in 2005. North Korea, Asia, and Western Europe are the chief producers of the world's wood demand [2]. Wolfgang and Burgess-Limerick [3] observed that the demand for sawn timber and wood products is rising globally and this trend is expected to continue. According to the Bureau of Labour and Statistics, sawmills are workshops where the woods obtained from the forests are turned into finished products through the use of industrial machines and sophisticated implements [4]. Furthermore, Zhao and Schindler argued that whenever these machines are used, vibrations become inevitable especially for the workers who operate them and work in sawmills [5].

According to Zinck [6], thousands of workers become exposed daily to highly repetitive, awkward postures and forceful exertions or vibrations while doing their jobs. These factors all contribute to the rising costs of claims for musculoskeletal disorders such as low back pain and carpal tunnel syndrome [7]. Also, Seidel [8] and Bovenzi et al., [9] explained that in industrial environments especially sawmills, workers often become exposed to varying levels of two different types of vibration, which are the whole-body vibration and hand-arm vibration. Furthermore, Mansfield [10] submitted that the whole-body vibrations are transmitted to all parts of the body while operating equipment, tools, and vehicles which eventually have different effects on the tissues and joints. 
The hand-arm vibration on the other hand according to European Union Parliament, is transmitted to the hands and arms when operating vibrating tools (chain saws and hand grinders) and vibrating controls (steering wheels and levers) [11). The International Organization for Standardization (ISO) [12] emphasized that exposure to hand-arm vibrations over several years can result in permanent physical damage commonly known as Raynaud's disease or White finger syndrome and the vibration can damage the muscles or joints of the wrist and elbow. Wilder [13] also confirmed that early symptoms of Raynaud's disease include pain, tingling, numbness or loss of feeling and control in the fingers, followed by blanching of the fingers caused by damage to the arteries and nerves in the hands. After a time, these symptoms may be irreversible. According to the Federal Environmental Protection Agency [14] and the Environmental Protection Authority [15], vibrations occurring between 8 $\mathrm{Hz}-1000 \mathrm{~Hz}$ are of concern when measuring hand-arm vibration, with frequencies in the range of $25 \mathrm{~Hz}-150 \mathrm{~Hz}$ associated with the development of Raynaud's disease. Also, Punnett et al., [16] said that the whole-body vibration is transmitted through the feet (standing on a vibrating surface), buttocks, or back (through the seat or backrest). Long term exposure can even result in serious physical damage to the low back or it can disturb the nervous system, while vibration levels occurring between $1 \mathrm{~Hz}-80 \mathrm{~Hz}$ are of most concern when measuring whole-body vibration [11; 17 and 18].

The Exposure Action Value (EAV) is a daily amount of vibration exposure above which workers are required to take action to control exposure while the Exposure Limit Value (ELV) is the maximum amount of vibration workers may be exposed per day. For hand-arm vibration, the EAV is a daily exposure of $2.5 \mathrm{~m} / \mathrm{s}^{2} \mathrm{~A}(8)$ and $\mathrm{ELV}$ is a daily exposure of 5 $\mathrm{m} / \mathrm{s}^{2} \mathrm{~A}(8)$. The EAV is equivalent to 100 points and ELV is equivalent to 400 points. However, a total exposure point value $\geq 100$ indicates an increased risk to employees, thus, there should be control to reduce the risk [19]. Also, total exposure point value $\geq 400$ shows that the workers have exceeded the safe limits and they are exposed to notable risk which is capable of leading to hand-arm vibration syndrome and immediate control should be implemented to reduce vibration magnitude exposure [19]. Consequently, this study sought to assess the vibration exposure of sawmilling workers using the hand-arm-vibration exposure analysis method to expose the threat of vibration on the operators and to recommend solutions to mitigate the effects of the vibration on the sawmill workers.

\section{MATERIALS, METHODS, AND DATA COLLECTION}

This study was carried out in Osun, Oyo, Ondo, Ekiti, Lagos, and the Ogun States of the Southwestern part of Nigeria where reconnaissance surveys were first carried out to select sawmills that were fully operational and thus, fit for this study. Consequently, two fully operational sawmills in two cities ( 2 sawmills per city) of each state were eventually selected and used for data collection, making a total of 24 sawmills visited. CMs, PMs, and BMs which are the commonest types of machinery in the sawmilling industries were considered. Two machines each of CMs, PMs, and BMs were considered in each sawmill selected, making a total of forty-eight (48) machines each of CMs, PMs and BMs.

Vibration level data were collected using Extech VB 450 vibration meter and all stabilized measurements were taken three times at different intervals. Data were also collected between the working hours of 7 am and 7 pm every day, for six days (Monday to Saturday). They usually started work early enough depending on the availability of electricity supply and whenever electricity was unavailable, the workers usually spent their time cleaning, arranging, and preparing the logs or planks for work before putting on the generator.

The sensor (housed in a magnetic adapter) was placed on the wood (where the operators held the wood) for CMs and PMs, while the sensor was placed on the machine (where the 
operators held the machine) for BMs. This was done to measure the exact vibration magnitude transmitted to the hand/arm as depicted in the HAV analysis. The magnitude (acceleration (Peak value) in $\mathrm{m} / \mathrm{s}^{2}$ ) of the $\mathrm{wood} / \mathrm{machines}$ and the exposure time were taken and compared with the Ready-Reckoner shown in Fig. 1. The daily EAV, ELV, and exposure points were then determined for each daily magnitude of the wood/machines using the HAV calculator [19].

\section{RESULTS AND DISCUSSION}

\subsection{Vibration Data Analysis}

The average Vibration Acceleration Magnitudes (VAM) before and after the break with their overall average are shown in Table 1, while the minimum and maximum VAM are shown in Table 2. Table 1 showed that the overall Average Wood Vibration Acceleration Magnitude (WVAM) in CMs and PMs during operations for each sawmill ranged from 34.2 to $104.1 \mathrm{~m} / \mathrm{s}^{2}$ and 104.1 to $173.7 \mathrm{~m} / \mathrm{s}^{2}$, respectively, while the Average Machine Vibration Acceleration Magnitude (MVAM) in BMs during operations for each sawmill ranged from 10.7 to $48.0 \mathrm{~m} / \mathrm{s}^{2}$. Also, the minimum and maximum WVAMs in CMs and PMs, and MVAMs in BMs for all sawmills are $32.2 / 106.7 \mathrm{~m} / \mathrm{s}^{2}, 99.1 / 187 \mathrm{~m} / \mathrm{s}^{2}$, and $10.2 / 49.3 \mathrm{~m} / \mathrm{s}^{2}$, respectively. Consequently, from Table 1, the least average WVAMs for all CMs $\left(34.2 \mathrm{~m} / \mathrm{s}^{2}(\mathrm{ON} 11)\right)$ and PMs $\left(104.1 \mathrm{~m} / \mathrm{s}^{2}(\mathrm{ON} 42)\right)$ and average MVAMs for BMs $\left(10.9 \mathrm{~m} / \mathrm{s}^{2}(\mathrm{OY} 41)\right)$ are more than the daily EAV (i.e. $2.5 \mathrm{~m} / \mathrm{s}^{2} \mathrm{~A}(8)$ ) and $\operatorname{ELV}$ (i.e. $5 \mathrm{~m} / \mathrm{s}^{2} \mathrm{~A}(8)$ ).

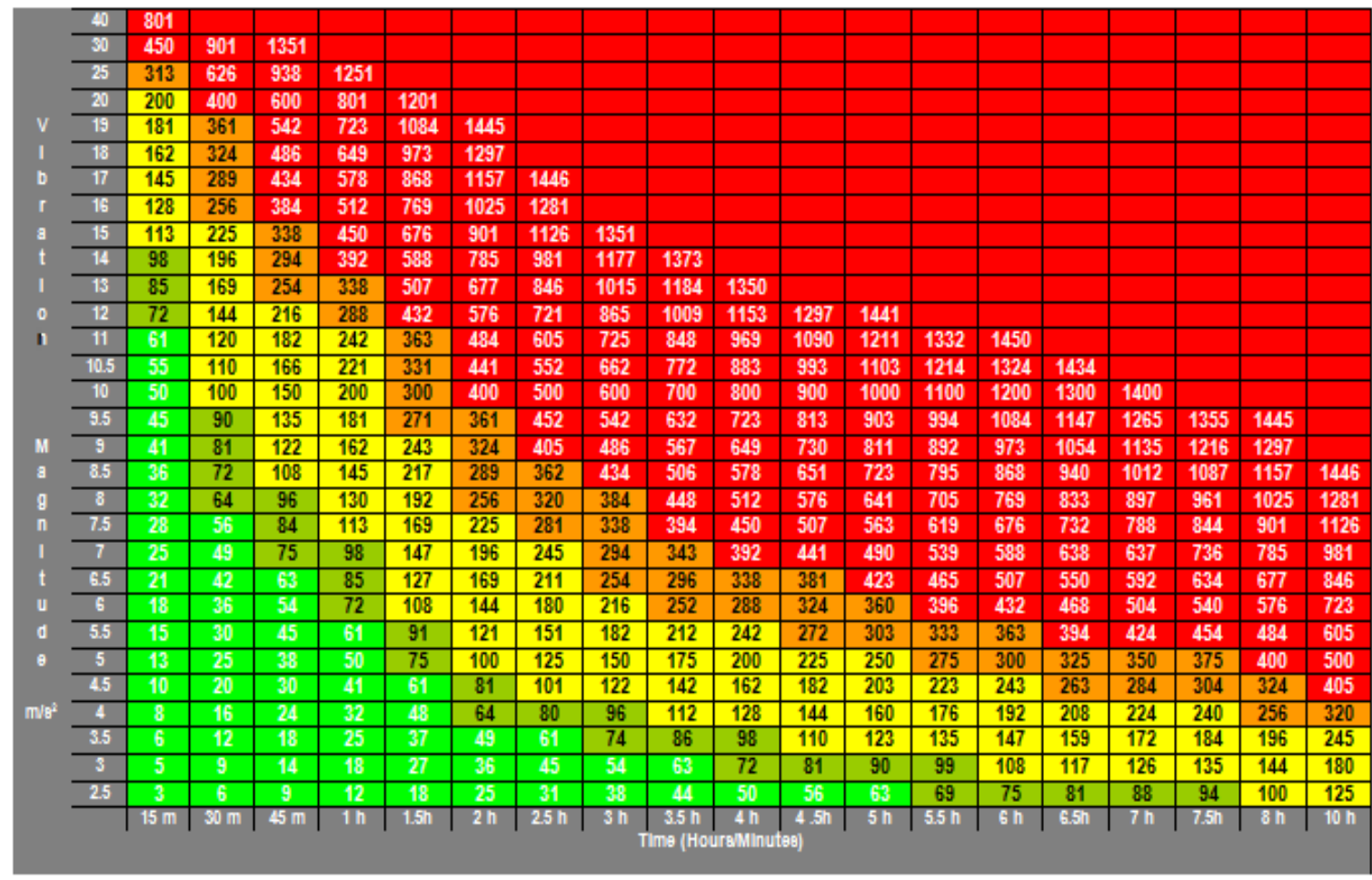

Figure 1 Ready-Reckoner Chart

The ANOVA results in Tables 3, 4, and 5 showed that there are statistically significant differences within the VAMs among the six states as their $\mathrm{P}$ values are $<0.05$ for the Wood Vibration Acceleration Magnitude (WVAM) in CM and PM and Machine Vibration Acceleration Magnitudes (MVAM) in BM. However, the tables also reflected that there are no statistically significant differences within all the samples taken, while the interaction within the samples and the machines in the six States as their $\mathrm{P}$ values are $>0.05$. But 
Abiola Olufemi Ajayeoba, Adewoye Alade Olanipekun, Oluwaseun Oluwagbemiga Ojo,

Oluremilekun Ropo Oyetunji and Wasiu Adewale Raheem

comparing the wood acceleration magnitude for $\mathrm{CM}$, PM, and BM acceleration magnitude levels, the ANOVA analysis in Table 6 revealed that there are statistically significant differences within the vibration acceleration magnitudes among the six States, within all the samples taken, within the interaction of the samples and the machines in the six States as their $\mathrm{P}$ values are $<0.05$.

Considering the wood acceleration magnitude level ANOVA analysis for CMs and PMs as shown in Tables 7 and 8 , the results showed that there are statistically significant differences within the vibration acceleration magnitudes among the six States as their P values are $<0.05$, but there are no statistically significant differences within all the samples taken, the interaction within the samples and the machines in the six States as their P values are > 0.05. Also in Table 9, BM acceleration magnitude ANOVA analysis for CMs and PMs showed statistically that, there are no significant differences within the vibration acceleration magnitudes among the six states, within all the samples taken and the interaction within the samples and the machines in the six states as their $\mathrm{P}$ values are $>0.05$.

Table 1 Average WVAMs in CMs and PMs and MVAMs in BMs Operations

\begin{tabular}{|c|c|c|c|c|c|c|c|c|c|c|}
\hline \multirow[b]{2}{*}{ State } & \multirow{2}{*}{ Sawmill } & \multicolumn{3}{|c|}{ WVAM ${ }_{\text {avrg }}$ on CMs $\left(\mathrm{m} / \mathrm{s}^{2}\right)$} & \multicolumn{3}{|c|}{ WVAM $M_{\text {avrg }}$ on PMs $\left(\mathrm{m} / \mathrm{s}^{2}\right)$} & \multicolumn{3}{|c|}{ MVAM ${ }_{\text {avrg }}$ on $B M s\left(\mathrm{~m} / \mathrm{s}^{2}\right)$} \\
\hline & & BB & AB & overall & BB & $\mathbf{A B}$ & Overall & BB & $\mathbf{A B}$ & Overall \\
\hline \multirow{8}{*}{ OS } & SM1 & 96.4 & 92.1 & 94.3 & 161.9 & 160.8 & 161.4 & 13.9 & 14.3 & 14.1 \\
\hline & SM2 & 83.7 & 81.8 & 82.8 & 143.3 & 146.2 & 144.8 & 15.5 & 15.8 & 15.7 \\
\hline & SM3 & 78.2 & 82.6 & 80.4 & 138.5 & 136.7 & 137.6 & 37.2 & 38.5 & 37.9 \\
\hline & SM4 & 82.0 & 80.8 & 81.4 & 135.1 & 133.6 & 134.4 & 25.1 & 25.5 & 25.3 \\
\hline & SM5 & 103.8 & 103.7 & 103.8 & 179.5 & 167.8 & 173.7 & 17.8 & 17.7 & 17.8 \\
\hline & SM6 & 82.6 & 81.2 & 81.9 & 162.9 & 161.8 & 162.4 & 19.4 & 19.8 & 19.6 \\
\hline & SM7 & 61.3 & 60.0 & 60.7 & 165.9 & 163.3 & 164.6 & 17.3 & 19.4 & 18.4 \\
\hline & SM8 & 66.4 & 69.0 & 67.7 & 142.4 & 142.7 & 142.6 & 17.9 & 20.1 & 19.0 \\
\hline \multirow{8}{*}{ ON } & SM1 & 33.8 & 34.6 & 34.2 & 103.2 & 105.3 & 104.3 & 14.4 & 15.4 & 14.9 \\
\hline & SM2 & 42.9 & 43.6 & 43.3 & 104.8 & 106.9 & 105.9 & 34.7 & 32.9 & 33.8 \\
\hline & SM3 & 33.6 & 36.5 & 35.1 & 122.6 & 120.8 & 121.7 & 37.0 & 37.5 & 37.3 \\
\hline & SM4 & 40.6 & 39.4 & 40.0 & 110.5 & 108.4 & 109.5 & 21.0 & 21.6 & 21.3 \\
\hline & SM5 & 91.4 & 90.5 & 91.0 & 110.8 & 115.7 & 113.3 & 17.7 & 18.1 & 17.9 \\
\hline & SM6 & 81.3 & 80.1 & 80.7 & 111.3 & 111.0 & 111.2 & 19.5 & 22.2 & 20.9 \\
\hline & SM7 & 89.6 & 90.4 & 90.0 & 106.0 & 105.5 & 105.8 & 23.1 & 21.1 & 22.1 \\
\hline & SM8 & 90.8 & 91.5 & 91.2 & 104.4 & 103.7 & 104.1 & 23.7 & 24.7 & 24.2 \\
\hline \multirow{8}{*}{ EK } & SM1 & 38.3 & 37.4 & 37.9 & 134.7 & 129.6 & 132.2 & 13.4 & 12.9 & 13.2 \\
\hline & SM2 & 35.7 & 36.6 & 36.2 & 111.6 & 110.3 & 111.0 & 13.7 & 14.9 & 14.3 \\
\hline & SM3 & 65.8 & 68.0 & 66.9 & 117.3 & 115.3 & 116.3 & 44.9 & 45.7 & 45.3 \\
\hline & SM4 & 74.4 & 73.3 & 73.9 & 115.2 & 112.0 & 113.6 & 25.3 & 26.8 & 26.1 \\
\hline & SM5 & 73.2 & 71.4 & 72.3 & 126.2 & 115.6 & 120.9 & 47.7 & 48.3 & 48.0 \\
\hline & SM6 & 76.0 & 73.9 & 75.0 & 114.6 & 111.8 & 113.2 & 44.3 & 45.0 & 44.7 \\
\hline & SM7 & 90.7 & 89.7 & 90.2 & 149.5 & 139.3 & 144.4 & 18.8 & 17.7 & 18.3 \\
\hline & SM8 & 103.4 & 104.7 & 104.1 & 123.1 & 122.0 & 122.6 & 20.4 & 19.4 & 19.9 \\
\hline \multirow{8}{*}{ OY } & SM1 & 73.2 & 71.3 & 72.3 & 158.6 & 157.4 & 158.0 & 16.6 & 17.6 & 17.1 \\
\hline & SM2 & 79.9 & 78.8 & 79.4 & 119.6 & 113.1 & 116.4 & 17.2 & 18.3 & 17.8 \\
\hline & SM3 & 33.8 & 34.6 & 34.2 & 142.8 & 130.4 & 136.6 & 22.7 & 23.8 & 23.3 \\
\hline & SM4 & 45.7 & 48.9 & 47.3 & 145.9 & 150.1 & 148.0 & 19.3 & 20.7 & 20.0 \\
\hline & SM5 & 65.8 & 68.3 & 67.1 & 134.5 & 128.0 & 131.3 & 44.3 & 41.9 & 43.1 \\
\hline & SM6 & 77.5 & 77.8 & 77.7 & 139.4 & 127.4 & 133.4 & 32.7 & 30.8 & 31.8 \\
\hline & SM7 & 61.1 & 60.2 & 60.7 & 149.3 & 153.2 & 151.3 & 10.4 & 10.9 & 10.7 \\
\hline & SM8 & 65.8 & 69.8 & 67.8 & 144.8 & 143.8 & 144.3 & 13.8 & 14.2 & 14.0 \\
\hline \multirow{8}{*}{ OG } & SM1 & 61.3 & 59.7 & 60.5 & 142.3 & 147.9 & 145.1 & 14.9 & 14.4 & 14.7 \\
\hline & SM2 & 66.6 & 70.8 & 68.7 & 129.6 & 134.5 & 132.1 & 26.4 & 26.2 & 26.3 \\
\hline & SM3 & 73.2 & 71.2 & 72.2 & 119.1 & 115.0 & 117.1 & 39.1 & 38.9 & 39.0 \\
\hline & SM4 & 72.9 & 71.8 & 72.4 & 120.7 & 116.8 & 118.8 & 18.8 & 20.4 & 19.6 \\
\hline & SM5 & 90.2 & 90.8 & 90.5 & 107.3 & 105.6 & 106.5 & 23.0 & 19.9 & 21.5 \\
\hline & SM6 & 94.8 & 90.1 & 92.5 & 107.9 & 106.1 & 107.0 & 37.5 & 37.4 & 37.5 \\
\hline & SM7 & 91.1 & 90.0 & 90.6 & 150.7 & 139.3 & 145.0 & 19.5 & 17.6 & 18.6 \\
\hline & SM8 & 90.1 & 89.5 & 89.8 & 139.0 & 126.9 & 133.0 & 18.9 & 16.9 & 17.9 \\
\hline LA & SM1 & 34.1 & 34.5 & 34.3 & 139.6 & 139.8 & 139.7 & 44.5 & 43.0 & 43.8 \\
\hline
\end{tabular}


Vibration Exposure Assessment of Sawmilling Operations using Hand-ARM-Vibration Exposure Analysis

\begin{tabular}{|l|l|l|l|l|l|l|l|l|l|l|}
\hline & SM2 & 50.4 & 49.9 & 50.2 & 112.3 & 113.0 & 112.7 & 12.9 & 13.8 & 13.4 \\
\cline { 2 - 10 } & SM3 & 89.6 & 90.5 & 90.1 & 106.0 & 105.4 & 105.7 & 12.3 & 12.9 & 12.6 \\
\cline { 2 - 10 } & SM4 & 85.7 & 85.1 & 85.4 & 111.2 & 111.2 & 111.2 & 32.4 & 30.3 & 31.4 \\
\cline { 2 - 10 } & SM5 & 71.1 & 70.1 & 70.6 & 111.9 & 115.0 & 113.5 & 17.6 & 17.4 & 17.5 \\
\cline { 2 - 10 } & SM6 & 64.2 & 66.2 & 65.2 & 112.8 & 111.8 & 112.3 & 16.0 & 15.1 & 15.6 \\
\cline { 2 - 10 } & SM7 & 67.9 & 68.8 & 68.4 & 130.7 & 126.3 & 128.5 & 14.9 & 14.8 & 14.9 \\
\cline { 2 - 10 } & SM8 & 71.6 & 69.6 & 70.6 & 199.4 & 132.6 & 166.0 & 18.3 & 18.1 & 18.2 \\
\hline
\end{tabular}

Table 2 Minimum and Maximum WVAMs in CMs and PMs and MVAMs in BMs.

\begin{tabular}{|c|c|c|c|c|c|c|c|}
\hline \multirow{2}{*}{ State } & \multirow[b]{2}{*}{ sawmill } & \multicolumn{2}{|c|}{ WVAMs in CMs $\left(\mathrm{m} / \mathrm{s}^{2}\right)$} & \multicolumn{2}{|c|}{ WVAMs in PM $\left(\mathrm{m} / \mathrm{s}^{2}\right)$} & \multicolumn{2}{|c|}{ MVAMs in BM $\left(\mathrm{m} / \mathrm{s}^{2}\right)$} \\
\hline & & Min & Max & Min & Max & Min & Max \\
\hline \multirow{8}{*}{ OS } & SM1 & 90.7 & 98.9 & 154.6 & 168.9 & 13.6 & 15.3 \\
\hline & SM2 & 81.4 & 84.6 & 138.5 & 152 & 15 & 16.1 \\
\hline & SM3 & 69.4 & 83.6 & 135.6 & 139.1 & 35.1 & 40 \\
\hline & SM4 & 80.1 & 82.7 & 132.7 & 136 & 23.1 & 27.3 \\
\hline & SM5 & 99.7 & 106.7 & 158.1 & 187 & 16.1 & 20.1 \\
\hline & SM6 & 79.9 & 84.2 & 156.4 & 169.9 & 18.2 & 21.3 \\
\hline & SM7 & 59.6 & 61.9 & 158.6 & 176.9 & 16.6 & 20 \\
\hline & SM8 & 62.7 & 72.5 & 137.1 & 150.1 & 16.9 & 20.9 \\
\hline \multirow{8}{*}{$\mathrm{ON}$} & SM1 & 32.2 & 35.9 & 99.1 & 110.6 & 13.7 & 16.5 \\
\hline & SM2 & 41.4 & 44.9 & 99.7 & 112.5 & 32.2 & 35.2 \\
\hline & SM3 & 32.3 & 40.7 & 118.5 & 126.9 & 34.9 & 39.1 \\
\hline & SM4 & 36.3 & 44.2 & 105.8 & 114.8 & 19.5 & 23.5 \\
\hline & SM5 & 89.4 & 93.1 & 101.1 & 121 & 15.9 & 20.3 \\
\hline & SM6 & 77.5 & 83.8 & 109.6 & 111.8 & 18.1 & 22.8 \\
\hline & SM7 & 88.6 & 91.2 & 99.8 & 110.8 & 20.2 & 23.8 \\
\hline & SM8 & 89.6 & 92.4 & 99.7 & 111.1 & 23.5 & 25.1 \\
\hline \multirow{8}{*}{ EK } & SM1 & 35.9 & 39.8 & 121.4 & 150.3 & 11.9 & 13.8 \\
\hline & SM2 & 34.5 & 38.2 & 109.9 & 112.8 & 13.2 & 15.3 \\
\hline & SM3 & 61 & 71.6 & 111.5 & 121.3 & 44.5 & 46.7 \\
\hline & SM4 & 71.2 & 75.3 & 109.6 & 121.7 & 24.9 & 27.2 \\
\hline & SM5 & 70.6 & 73.8 & 109.4 & 130.7 & 46.4 & 49.3 \\
\hline & SM6 & 72.9 & 76.6 & 110.3 & 121 & 42.6 & 46.4 \\
\hline & SM7 & 88.3 & 91.1 & 129.4 & 157 & 17.1 & 19.4 \\
\hline & SM8 & 101.8 & 105.6 & 121.1 & 124.2 & 19 & 21.5 \\
\hline \multirow{8}{*}{ OY } & SM1 & 70.6 & 73.8 & 148.6 & 168.9 & 16.1 & 17.9 \\
\hline & SM2 & 77.6 & 81.4 & 107.3 & 135 & 16.8 & 18.8 \\
\hline & SM3 & 32.2 & 35.9 & 112.9 & 157 & 21.2 & 23.9 \\
\hline & SM4 & 44.2 & 53.4 & 143.1 & 155.3 & 18.1 & 20.9 \\
\hline & SM5 & 61.9 & 71.6 & 122.2 & 150.2 & 41.5 & 46.4 \\
\hline & SM6 & 76.6 & 78.9 & 110 & 153.9 & 29.8 & 34.9 \\
\hline & SM7 & 59.5 & 61.9 & 146.9 & 158.5 & 10.2 & 11.2 \\
\hline & SM8 & 63.4 & 74.6 & 139.2 & 153 & 13.3 & 14.7 \\
\hline \multirow{8}{*}{ OG } & SM1 & 58.7 & 61.9 & 135.4 & 156.2 & 14.2 & 15.1 \\
\hline & SM2 & 57.7 & 71.9 & 123.1 & 143.7 & 26.2 & 26.5 \\
\hline & SM3 & 70.6 & 73.8 & 110.7 & 132.4 & 38.4 & 39.8 \\
\hline & SM4 & 71 & 73.6 & 111.9 & 134.5 & 18.6 & 20.7 \\
\hline & SM5 & 89.3 & 91.6 & 101.4 & 111.3 & 19.5 & 23.5 \\
\hline & SM6 & 88.8 & 96.8 & 101.6 & 112 & 36.6 & 38.6 \\
\hline & SM7 & 88.9 & 92.1 & 132.7 & 153.2 & 16.9 & 20.3 \\
\hline & SM8 & 86.7 & 92.7 & 120 & 141.3 & 16 & 19.6 \\
\hline \multirow{8}{*}{ LA } & SM1 & 32.2 & 36.3 & 137.5 & 141.2 & 42.7 & 45.8 \\
\hline & SM2 & 47.9 & 52.1 & 110.1 & 114.6 & 12.3 & 14.5 \\
\hline & SM3 & 88.6 & 91.2 & 99.4 & 110.8 & 12 & 13.1 \\
\hline & SM4 & 84.7 & 86.8 & 110.2 & 112.2 & 30.1 & 33.5 \\
\hline & SM5 & 67.6 & 72.1 & 110.6 & 121.2 & 16.1 & 18.9 \\
\hline & SM6 & 59.8 & 70.2 & 110.5 & 113.2 & 14 & 17.7 \\
\hline & SM7 & 65.5 & 71.1 & 123.5 & 133.2 & 14.5 & 15.2 \\
\hline & SM8 & 68.7 & 72.6 & 131.2 & 133.4 & 17.8 & 19 \\
\hline \multicolumn{2}{|l|}{ MIN } & 32.2 & 35.9 & 99.1 & 110.6 & 10.2 & 11.2 \\
\hline MAX & & 101.8 & 106.7 & 158.6 & 187 & 46.4 & 49.3 \\
\hline
\end{tabular}


Abiola Olufemi Ajayeoba, Adewoye Alade Olanipekun, Oluwaseun Oluwagbemiga Ojo,

Oluremilekun Ropo Oyetunji and Wasiu Adewale Raheem

Table 3 ANOVA analysis results of comparison within WVAMs during the working period of the CMs

\begin{tabular}{|l|c|c|c|c|c|c|}
\hline \multicolumn{1}{|c|}{$\begin{array}{c}\text { Source of } \\
\text { Variation }\end{array}$} & SS & df & MS & F & P-value & F crit \\
\hline States & 15691.34 & 5 & 3138.269 & 8.526992 & $1.78 \mathrm{E}-07$ & 2.249846 \\
\hline Samples & 189.2849 & 5 & 37.85697 & 0.102861 & 0.991494 & 2.249846 \\
\hline Interaction & 98.00014 & 25 & 3.920006 & 0.010651 & 1 & 1.549845 \\
\hline Within & 92745.93 & 252 & 368.0394 & & & \\
\hline Total & 108724.6 & 287 & & & & \\
\hline
\end{tabular}

Table 4 ANOVA analysis results of comparison within WVAMs during the working period of the PMs

\begin{tabular}{|l|c|c|c|c|c|c|}
\hline \multicolumn{1}{|c|}{$\begin{array}{c}\text { Source of } \\
\text { Variation }\end{array}$} & SS & df & MS & F & P-value & F crit \\
\hline States & 55389.2 & 5 & 11077.84 & 31.27186 & $1 \mathrm{E}-24$ & 2.249846 \\
\hline Samples & 3929.909 & 5 & 785.9818 & 2.218764 & 0.052973 & 2.249846 \\
\hline Interaction & 3168.822 & 25 & 126.7529 & 0.357813 & 0.998331 & 1.549845 \\
\hline Within & 89269.27 & 252 & 354.2431 & & & \\
\hline Total & 151757.2 & 287 & & & & \\
\hline
\end{tabular}

Table 5 ANOVA analysis results of comparison within MVAMs during the working period of the BMs

\begin{tabular}{|l|l|l|l|l|l|l|}
\hline $\begin{array}{l}\text { Source of } \\
\text { Variation }\end{array}$ & SS & df & MS & F & P-value & F crit \\
\hline States & 2059.815 & 5 & 411.9631 & 3.751725 & 0.002706 & 2.249846 \\
\hline Samples & 11.55781 & 5 & 2.311563 & 0.021051 & 0.999813 & 2.249846 \\
\hline Interaction & 49.24031 & 25 & 1.969612 & 0.017937 & 1 & 1.549845 \\
\hline Within & 27671.19 & 252 & 109.8063 & & & \\
\hline Total & 29791.8 & 287 & & & & \\
\hline
\end{tabular}

Table 6 ANOVA analysis results of comparison within WVAMs during the working period of the CMs and PMs and MVAMs during the working period of BMs

\begin{tabular}{|l|c|c|c|c|c|c|}
\hline \multicolumn{1}{|c|}{$\begin{array}{c}\text { Source of } \\
\text { Variation }\end{array}$} & SS & df & MS & F & P-value & F crit \\
\hline Sample & 5130.326 & 5 & 1026.065 & 4.569086 & 0.00073 & 2.286184 \\
\hline Columns & 267098.9 & 2 & 133549.4 & 594.6979 & $6.65 \mathrm{E}-65$ & 3.0681 \\
\hline Interaction & 7055.316 & 10 & 705.5316 & 3.141744 & 0.001285 & 1.90661 \\
\hline Within & 28295.42 & 126 & 224.5668 & & & \\
\hline Total & 307579.9 & 143 & & & & \\
\hline
\end{tabular}

Table 7 ANOVA analysis results of comparison within WVAMs during the working period of the CMs before and after the break

\begin{tabular}{|l|c|c|c|c|c|c|}
\hline \multicolumn{1}{|c|}{$\begin{array}{c}\text { Source of } \\
\text { Variation }\end{array}$} & SS & df & MS & F & P-value & F crit \\
\hline Sample & 5228.125 & 5 & 1045.625 & 2.867774 & 0.019348 & 2.323126 \\
\hline Columns & 0.06 & 1 & 0.06 & 0.000165 & 0.989795 & 3.954568 \\
\hline Interaction & 6.85 & 5 & 1.37 & 0.003757 & 0.999997 & 2.323126 \\
\hline Within & 30627.42 & 84 & 364.6121 & & & \\
\hline Total & 35862.45 & 95 & & & & \\
\hline
\end{tabular}


Table 8 ANOVA analysis results of comparison within WVAMs during the working period of the PMs before and after the break

\begin{tabular}{|l|c|c|c|c|c|c|}
\hline \multicolumn{1}{|c|}{$\begin{array}{c}\text { Source of } \\
\text { Variation }\end{array}$} & SS & df & MS & F & P-value & F crit \\
\hline Sample & 18454.29 & 5 & 3690.858 & 16.07707 & $4.3 \mathrm{E}-11$ & 2.323126 \\
\hline Columns & 315.375 & 1 & 315.375 & 1.373747 & 0.244483 & 3.954568 \\
\hline Interaction & 180.43 & 5 & 36.086 & 0.157188 & 0.977278 & 2.323126 \\
\hline Within & 19284.12 & 84 & 229.5728 & & & \\
\hline Total & 38234.21 & 95 & & & & \\
\hline
\end{tabular}

Table 9 ANOVA analysis results of comparison within the MVAMs during the working period of the BMs before and after the break

\begin{tabular}{|l|l|l|l|l|l|l|}
\hline \multicolumn{1}{|c|}{$\begin{array}{c}\text { Source of } \\
\text { Variation }\end{array}$} & \multicolumn{1}{c|}{ SS } & \multicolumn{1}{c|}{ df } & \multicolumn{1}{c|}{ MS } & F & P-value & F crit \\
\hline Sample & 688.8705 & 5 & 137.7741 & 1.261087 & 0.288431 & 2.323126 \\
\hline Columns & 0.087604 & 1 & 0.087604 & 0.000802 & 0.977476 & 3.954568 \\
\hline Interaction & 7.053021 & 5 & 1.410604 & 0.012912 & 0.999943 & 2.323126 \\
\hline Within & 9177.024 & 84 & 109.2503 & & & \\
\hline Total & 9873.035 & 95 & & & & \\
\hline
\end{tabular}

\subsection{Vibration Exposure Analysis}

Table 10 (the minimum, maximum and average working hour) revealed that the least time spent on CMs, PMs, and BMs are 1.91 (LA31), 2.07 (EK41), and 1.43 hrs (EK41), respectively while the highest time spent on CMs, PMs and BMs are 4.69 (ON22), 7.55 (OS21) and 6.96 hrs (ON42), respectively. CMs are more than the PMs and BMs in all the visited sawmills, thus, more CMs were working at the same time compared with the number of PMs and BMs working per day. Consequently, the working hour on each CM was lesser compared with PM and BM because there were many CMs to do the needed work compared with the few available PMs and BMs. Table 11, which shows the calculated EAV, ELV, and total exposure points for CMs, PMs, and BMs, revealed that with minimum/maximum EAV and ELV of PMs lesser than zero minutes was an indication that the WVAM and exposure time were too high as shown in tables 1 and 10 and thus, made PMs have the highest average exposure points. However, even though BMs have higher exposure time compared with CMs, the BM vibration acceleration magnitude is lesser compared with CM's Wood Vibration Acceleration Magnitude (WVAM), herewith this reason, the CMs had higher average exposure points, compared with the BMs. However, BMs having the least vibration acceleration magnitude might be to the facts that the Machine Vibration Acceleration Magnitude (MVAV) was measured (because the operators were holding the handles of the machine and not the wood) compared with the CMs and PMs where the operators were holding (pushing and pulling) the wood logs. Though all the machine average exposure points were well above 400 points, and according to Health and Safety Executive [20], exposure limit value is a level of vibration exposure that must not be exceeded, therefore, necessary actions like looking for ways to reduce the vibration magnitude by use of dampers, change all the machinery to new ones or reduce the workers' exposure time use be adopted. 
Abiola Olufemi Ajayeoba, Adewoye Alade Olanipekun, Oluwaseun Oluwagbemiga Ojo,

Oluremilekun Ropo Oyetunji and Wasiu Adewale Raheem

Table 10 Minimum, Maximum and Average Time spent on each Machine

\begin{tabular}{|c|c|c|c|c|c|c|c|c|c|c|c|}
\hline \multirow[b]{2}{*}{ Sawmills } & \multicolumn{3}{|c|}{ CMs } & \multirow[b]{2}{*}{ Sawmills } & \multicolumn{3}{|c|}{ PMs } & \multirow[b]{2}{*}{ Sawmills } & \multicolumn{3}{|c|}{ BMs } \\
\hline & $\begin{array}{l}\text { Min } \\
\text { (hr) }\end{array}$ & $\begin{array}{c}\text { Max } \\
\text { (hr) }\end{array}$ & $\begin{array}{c}\text { Average } \\
\text { (hr) }\end{array}$ & & $\begin{array}{l}\text { Min } \\
\text { (hr) }\end{array}$ & $\begin{array}{c}\text { Max } \\
\text { (hr) }\end{array}$ & $\begin{array}{c}\text { Average } \\
\text { (hr) }\end{array}$ & & $\begin{array}{l}\text { Min } \\
\text { (hr) }\end{array}$ & $\begin{array}{c}\text { Max } \\
\text { (hr) }\end{array}$ & $\begin{array}{c}\text { Average } \\
\text { (hr) }\end{array}$ \\
\hline LA42 & 1.96 & 2.58 & 2.31 & EK41 & 2.07 & 6.56 & 3.63 & OS41 & 2.15 & 3.39 & 2.83 \\
\hline LA31 & 1.91 & 2.64 & 2.33 & EK32 & 3.12 & 4.04 & 3.75 & OS32 & 2.05 & 4.41 & 3.00 \\
\hline EK41 & 2.45 & 2.66 & 2.55 & LA32 & 2.23 & 6.05 & 3.76 & ON32 & 2.38 & 3.48 & 3.02 \\
\hline ON41 & 2.50 & 2.76 & 2.64 & OS22 & 2.53 & 4.88 & 3.77 & OS42 & 2.15 & 4.24 & 3.10 \\
\hline ON42 & 2.58 & 2.84 & 2.69 & OG32 & 2.53 & 5.67 & 3.87 & OY31 & 2.15 & 4.10 & 3.14 \\
\hline EK11 & 2.59 & 2.90 & 2.76 & OY21 & 3.36 & 4.84 & 4.04 & OY12 & 2.06 & 4.02 & 3.26 \\
\hline LA21 & 2.54 & 2.99 & 2.83 & LA11 & 3.10 & 5.27 & 4.06 & OG32 & 2.15 & 4.21 & 3.38 \\
\hline LA12 & 2.64 & 3.08 & 2.91 & EK21 & 3.15 & 5.13 & 4.07 & ON22 & 2.01 & 4.18 & 3.39 \\
\hline OS42 & 2.68 & 3.11 & 2.96 & OY31 & 3.42 & 5.51 & 4.15 & OY21 & 2.70 & 4.10 & 3.45 \\
\hline OG22 & 2.54 & 3.26 & 2.97 & LA12 & 3.66 & 5.24 & 4.15 & LA32 & 2.32 & 5.17 & 3.49 \\
\hline OS21 & 2.65 & 3.17 & 2.99 & OY32 & 3.13 & 5.53 & 4.20 & EK11 & 2.37 & 4.59 & 3.50 \\
\hline OY32 & 2.47 & 3.35 & 2.99 & ON41 & 3.71 & 4.64 & 4.22 & OS21 & 2.60 & 4.11 & 3.52 \\
\hline OG12 & 2.67 & 3.17 & 3.00 & OY12 & 3.61 & 4.86 & 4.23 & ON31 & 2.98 & 4.16 & 3.52 \\
\hline EK22 & 2.84 & 3.16 & 3.02 & ON21 & 3.30 & 4.66 & 4.28 & EK32 & 2.76 & 4.20 & 3.52 \\
\hline LA11 & 2.79 & 3.27 & 3.05 & OS41 & 3.86 & 5.33 & 4.30 & EK12 & 2.93 & 4.26 & 3.58 \\
\hline LA41 & 2.88 & 3.23 & 3.06 & OG12 & 4.07 & 4.74 & 4.40 & EK41 & 1.43 & 4.71 & 3.58 \\
\hline OS11 & 2.88 & 3.22 & 3.08 & OY42 & 3.79 & 5.72 & 4.50 & LA11 & 2.63 & 4.60 & 3.59 \\
\hline OY31 & 2.93 & 3.28 & 3.11 & OY41 & 2.72 & 5.17 & 4.51 & OS22 & 2.32 & 4.48 & 3.75 \\
\hline LA22 & 2.94 & 3.33 & 3.18 & OS42 & 3.89 & 5.93 & 4.56 & LA21 & 2.73 & 5.21 & 3.76 \\
\hline ON12 & 2.92 & 3.35 & 3.20 & OG21 & 3.96 & 5.74 & 4.65 & OG11 & 3.07 & 4.48 & 3.80 \\
\hline OS12 & 2.87 & 3.39 & 3.21 & ON22 & 3.35 & 6.09 & 4.66 & OY42 & 3.34 & 4.91 & 3.84 \\
\hline EK21 & 3.10 & 3.37 & 3.22 & ON12 & 4.51 & 5.06 & 4.66 & OG21 & 3.19 & 4.78 & 3.90 \\
\hline OG42 & 2.90 & 3.42 & 3.22 & LA42 & 4.18 & 5.15 & 4.67 & OY22 & 2.33 & 6.16 & 3.92 \\
\hline OG41 & 2.94 & 3.40 & 3.23 & OS11 & 3.44 & 5.37 & 4.75 & EK22 & 3.44 & 4.93 & 3.94 \\
\hline OY41 & 2.72 & 3.60 & 3.24 & ON32 & 4.06 & 5.34 & 4.76 & OS31 & 3.33 & 5.17 & 3.96 \\
\hline OY22 & 2.98 & 3.58 & 3.31 & ON42 & 3.48 & 5.69 & 4.78 & ON41 & 3.52 & 4.23 & 3.98 \\
\hline ON11 & 3.10 & 3.52 & 3.34 & OG42 & 4.17 & 5.18 & 4.79 & OS12 & 3.38 & 4.43 & 4.03 \\
\hline OS32 & 3.02 & 3.63 & 3.41 & OY22 & 3.40 & 6.00 & 4.85 & OG41 & 2.28 & 7.59 & 4.14 \\
\hline OG32 & 2.95 & 3.75 & 3.43 & LA21 & 3.41 & 5.70 & 4.91 & EK42 & 3.70 & 4.67 & 4.18 \\
\hline OG31 & 3.32 & 3.82 & 3.65 & EK11 & 3.65 & 6.01 & 4.93 & OS11 & 3.23 & 5.10 & 4.25 \\
\hline OY21 & 3.48 & 3.87 & 3.67 & ON11 & 4.26 & 5.44 & 4.98 & OG22 & 2.87 & 6.04 & 4.31 \\
\hline EK42 & 3.52 & 3.83 & 3.69 & OG11 & 4.51 & 7.01 & 5.01 & LA31 & 3.48 & 5.92 & 4.33 \\
\hline OG11 & 3.43 & 3.99 & 3.74 & OG31 & 3.90 & 5.88 & 5.07 & EK21 & 3.27 & 5.78 & 4.34 \\
\hline OS22 & 3.37 & 3.97 & 3.76 & EK22 & 4.44 & 5.61 & 5.10 & OY32 & 2.98 & 5.21 & 4.36 \\
\hline OY12 & 3.52 & 4.02 & 3.78 & OG22 & 3.50 & 6.01 & 5.14 & LA12 & 3.21 & 4.83 & 4.41 \\
\hline ON21 & 3.70 & 3.87 & 3.80 & OG41 & 2.55 & 7.11 & 5.15 & OY41 & 3.99 & 5.21 & 4.49 \\
\hline OG21 & 3.12 & 4.40 & 3.89 & ON31 & 4.62 & 6.28 & 5.26 & ON11 & 4.03 & 5.38 & 4.58 \\
\hline ON32 & 3.84 & 4.09 & 3.97 & OY11 & 4.90 & 5.78 & 5.28 & ON12 & 4.01 & 4.98 & 4.59 \\
\hline OY42 & 3.31 & 4.58 & 4.07 & EK31 & 4.65 & 5.63 & 5.30 & OG12 & 3.36 & 5.29 & 4.66 \\
\hline OS31 & 3.61 & 4.33 & 4.08 & LA22 & 4.56 & 6.65 & 5.35 & LA41 & 3.34 & 6.76 & 4.73 \\
\hline EK12 & 4.01 & 4.24 & 4.13 & LA41 & 3.74 & 6.42 & 5.38 & OY11 & 3.86 & 6.34 & 4.74 \\
\hline OS41 & 3.85 & 4.37 & 4.14 & OS32 & 4.19 & 6.55 & 5.40 & OG31 & 4.04 & 5.77 & 4.76 \\
\hline OY11 & 4.12 & 4.45 & 4.29 & LA31 & 4.84 & 5.91 & 5.49 & EK31 & 3.47 & 5.87 & 4.79 \\
\hline EK31 & 4.29 & 4.56 & 4.42 & OS12 & 5.16 & 6.59 & 5.67 & OG42 & 4.51 & 5.40 & 4.85 \\
\hline LA32 & 4.18 & 4.62 & 4.43 & EK12 & 4.31 & 6.54 & 5.97 & LA22 & 4.43 & 5.42 & 4.85 \\
\hline EK32 & 4.34 & 4.66 & 4.51 & OS31 & 4.87 & 7.00 & 6.00 & ON21 & 4.19 & 5.93 & 5.06 \\
\hline ON31 & 4.46 & 4.66 & 4.56 & EK42 & 5.50 & 7.07 & 6.28 & LA42 & 3.95 & 6.32 & 5.41 \\
\hline ON22 & 4.41 & 4.69 & 4.58 & OS21 & 5.93 & 7.55 & 6.69 & ON42 & 4.54 & 6.96 & 5.67 \\
\hline
\end{tabular}


Table 11 Calculated EAV, ELV and Total Exposure Points for CMs, PMs, and BMs

\begin{tabular}{|c|c|c|c|c|c|c|c|c|c|c|c|}
\hline \multicolumn{4}{|c|}{ CMs } & \multicolumn{4}{|c|}{ PMs } & \multicolumn{4}{|c|}{ BMs } \\
\hline Sawmill & $\begin{array}{l}\text { Time to } \\
\text { Reach } \\
\text { EAV } \\
\text { (min) }\end{array}$ & $\begin{array}{l}\text { Time to } \\
\text { Reach } \\
\text { ELV } \\
\text { (min) }\end{array}$ & $\begin{array}{c}\text { Exposure } \\
\text { Points }\end{array}$ & Sawmill & $\begin{array}{l}\text { Time to } \\
\text { Reach } \\
\text { EAV } \\
\text { (min) }\end{array}$ & $\begin{array}{l}\text { Time to } \\
\text { Reach } \\
\text { ELV } \\
\text { (min) }\end{array}$ & $\begin{array}{c}\text { Exposure } \\
\text { Points }\end{array}$ & Sawmill & $\begin{array}{l}\text { Time to } \\
\text { Reach } \\
\text { EAV } \\
\text { (min) }\end{array}$ & $\begin{array}{l}\text { Time to } \\
\text { Reach } \\
\text { ELV } \\
\text { (min) }\end{array}$ & $\begin{array}{c}\text { Exposure } \\
\text { Points }\end{array}$ \\
\hline LA11 & 3 & 10 & 7314.59 & OG32 & 0 & 1 & 90555.73 & OY41 & 26 & 105 & $\begin{array}{l}1038.02 \\
\end{array}$ \\
\hline ON11 & 3 & 10 & 7964.37 & ON41 & 0 & 1 & 95346.19 & LA21 & 19 & 76 & 1205.47 \\
\hline EK11 & 2 & 8 & 8061.12 & EK32 & 0 & 1 & 96155.75 & EK11 & 17 & 9 & 1231.70 \\
\hline OY21 & 3 & 10 & 8750.62 & LA32 & 0 & 1 & 97191.25 & EK12 & 15 & 59 & 1477.84 \\
\hline ON21 & 2 & 10 & 9516.50 & ON42 & 0 & 1 & 105493.50 & OY42 & 15 & 61 & 1520.20 \\
\hline EK12 & 2 & 9 & 11002.43 & LA12 & 0 & 1 & 105612.05 & LA12 & 17 & 67 & 1598.89 \\
\hline ON12 & 2 & 6 & 12202.18 & ON12 & 0 & 1 & 106898.83 & OG11 & 14 & 56 & 1658.40 \\
\hline LA12 & 1 & 5 & 14919.44 & ON11 & 0 & 1 & 110311.32 & OS11 & 15 & 60 & 1705.82 \\
\hline ON22 & 2 & 8 & $\begin{array}{l}14938.79 \\
\end{array}$ & LA21 & 0 & 1 & 111026.65 & LA32 & 12 & 49 & 1714.89 \\
\hline OY22 & 1 & 5 & 15096.65 & EK21 & 0 & 1 & 112467.43 & OS41 & 9 & 35 & 1934.80 \\
\hline LA42 & 1 & 2 & 23471.45 & ON22 & 0 & 1 & 114290.20 & OS12 & 12 & 49 & 2005.42 \\
\hline LA31 & 1 & 2 & 23675.15 & OY12 & 0 & 1 & 115408.79 & ON11 & 14 & 54 & 2052.83 \\
\hline OY41 & 1 & 3 & 24296.41 & OG31 & 0 & 1 & 117314.64 & OY12 & 9 & 38 & 2085.11 \\
\hline OS42 & 1 & 3 & 27656.31 & ON32 & 0 & 1 & 120374.53 & LA41 & 14 & 54 & 2120.42 \\
\hline OG11 & 1 & 3 & 27906.85 & OG21 & 0 & 1 & 127924.98 & OS42 & 8 & 33 & 2259.63 \\
\hline OY31 & 1 & 3 & 28502.65 & ON21 & 0 & 1 & 129161.10 & ON31 & 9 & 37 & 2277.78 \\
\hline OG12 & 1 & 3 & 28864.20 & EK22 & 0 & 1 & 133478.39 & OS32 & 8 & 31 & 2327.21 \\
\hline LA41 & 1 & 3 & 29142.24 & LA22 & 0 & 1 & 135420.72 & EK41 & 9 & 36 & 2421.03 \\
\hline EK21 & 1 & 3 & 29378.53 & ON31 & 0 & 1 & 137981.10 & OS31 & 9 & 38 & 2533.00 \\
\hline OS41 & 1 & 3 & 31044.73 & OS22 & 0 & 1 & 139208.10 & ON32 & 7 & 27 & 2663.13 \\
\hline OG22 & 1 & 2 & 31692.47 & OY31 & 0 & 1 & 143349.09 & LA31 & 10 & 39 & 2677.25 \\
\hline EK22 & 1 & 2 & 33576.62 & LA31 & 0 & 1 & 143693.58 & OY11 & 10 & 41 & 2798.30 \\
\hline OY32 & 0 & 2 & 36752.18 & OG22 & 0 & 1 & 145977.36 & OG41 & 9 & 35 & 2892.12 \\
\hline OY42 & 1 & 3 & 38140.35 & EK12 & 0 & 1 & 149926.86 & ON22 & 7 & 26 & 3105.98 \\
\hline LA32 & 1 & 3 & 38390.89 & OY21 & 0 & 1 & 151371.70 & OG42 & 9 & 37 & 3138.26 \\
\hline OS21 & 0 & 2 & 39401.20 & OY32 & 0 & 1 & 151580.42 & OY22 & 8 & 30 & 3166.50 \\
\hline OG21 & 1 & 2 & $\begin{array}{l}41338.31 \\
\end{array}$ & EK41 & 0 & 1 & 152236.98 & EK42 & 8 & 30 & 3342.03 \\
\hline EK41 & 0 & 1 & 42294.65 & OG12 & 0 & 1 & 155718.37 & OG22 & 8 & 31 & 3343.03 \\
\hline ON41 & 0 & 1 & 43593.19 & EK31 & 0 & 1 & 157112.55 & LA42 & 9 & 36 & 3618.43 \\
\hline OS12 & 0 & 2 & 44809.23 & LA11 & 0 & 1 & 162277.90 & OY21 & 6 & 22 & 3781.85 \\
\hline ON42 & 0 & 1 & 45560.85 & OG42 & 0 & 1 & 172197.24 & ON41 & 6 & 25 & 3925.09 \\
\hline OY11 & 1 & 2 & 45652.52 & EK11 & 0 & 1 & 173676.52 & OG31 & 6 & 26 & 4442.58 \\
\hline OS32 & 0 & 2 & 46628.20 & LA41 & 0 & 1 & 180834.86 & OS22 & 5 & 19 & 4847.10 \\
\hline LA21 & 0 & 1 & 46781.99 & OS42 & 0 & 1 & 189705.52 & EK22 & 4 & 18 & 5419.07 \\
\hline EK31 & 1 & 2 & 47100.77 & OY42 & 0 & 1 & 190032.79 & OG12 & 4 & 17 & 6508.53 \\
\hline LA22 & 0 & 2 & 47279.00 & EK42 & 0 & 1 & 192046.04 & ON42 & 5 & 20 & 6705.24 \\
\hline OY12 & 0 & 2 & $\begin{array}{l}48519.48 \\
\end{array}$ & OY41 & 0 & 1 & 208917.02 & OY32 & 3 & 12 & 8902.32 \\
\hline OS22 & 0 & 2 & 50788.61 & OY22 & 0 & 1 & 213229.24 & OG32 & 2 & 9 & 9597.35 \\
\hline EK32 & 1 & 2 & 51647.18 & OG11 & 0 & 1 & 213494.70 & LA22 & 3 & 12 & 9655.86 \\
\hline ON32 & 0 & 2 & 52706.38 & OG41 & 0 & 1 & 217464.46 & OS21 & 2 & 8 & 10209.67 \\
\hline OG42 & 0 & 1 & 52934.51 & OS41 & 0 & 0 & 236271.69 & ON12 & 3 & 11 & 10587.96 \\
\hline OG41 & 0 & 1 & \begin{tabular}{|l|}
53989.64 \\
\end{tabular} & OS12 & 0 & 1 & 242379.32 & OY31 & 2 & 6 & $\begin{array}{l}11777.29 \\
\end{array}$ \\
\hline OS11 & 0 & 1 & 55775.00 & OS11 & 0 & 0 & 253589.49 & OG21 & 2 & 8 & 11977.02 \\
\hline OG32 & 0 & 1 & 59763.29 & OS21 & 0 & 1 & 257273.52 & LA11 & 2 & 6 & 13906.78 \\
\hline OG31 & 0 & 1 & 60941.65 & LA42 & 0 & 0 & 262661.78 & EK32 & 2 & 6 & 14201.34 \\
\hline ON31 & 0 & 1 & $\begin{array}{l}76894.83 \\
\end{array}$ & OY11 & 0 & 0 & 268332.72 & ON21 & 2 & 9 & 14214.45 \\
\hline EK42 & 0 & 1 & 81440.22 & OS32 & 0 & 0 & 288834.03 & EK21 & 1 & 6 & $\begin{array}{l}17983.19 \\
\end{array}$ \\
\hline OS 31 & 0 & 1 & 89528.84 & OS31 & 0 & 0 & 367142.07 & EK31 & 1 & 5 & 22283.53 \\
\hline
\end{tabular}

\section{CONCLUSIONS}

All the machine average exposure points were well above 400 points and the least average WVAMs for all CMs and PMs and average MVAMs for BMs are more than the daily EAV and ELV. Thus, the study concluded that the contributing factors responsible for the high values of the exposure analysis experienced by workers were; poor machine damping, use of old and obsolete machines, poor working conditions, and general negligence by workers to 
Abiola Olufemi Ajayeoba, Adewoye Alade Olanipekun, Oluwaseun Oluwagbemiga Ojo,

Oluremilekun Ropo Oyetunji and Wasiu Adewale Raheem

the use of the required personal protective equipment, lack of proper working tools, worker's carelessness and lack of required training.

It is hereby recommended that working tools should be provided, vibration damper should be installed, use of personal protective equipment should be encouraged, workers should be given adequate training, new, the workers' exposure time should be reduced, new and modern machines should be procured and workers attitude to occupational safety should improve.

\section{ACKNOWLEDGMENT}

This is to acknowledge the Tertiary Education Trust Fund (TETFUND) as the sole sponsor of this research work through the Institutional Based Research (IBR) grant (Ladoke Akintola University of Technology, Ogbomoso, Nigeria) (2016).

\section{REFERENCES}

[1] M.J. Griffin. Negligent Exposures to Hand-Transmitted Vibration. International Archives of Occupational and Environmental Health, 81, (5); (2007), 645 - 659.

[2] M. Bovenzi. Health Risks from Occupational Exposures to Mechanical Vibration. La Medicina del Lavoro, 97, (3); (2006), 535 - 541.

[3] R. Wolfgang, R. Burgess-Limerick. Whole-Body Vibration Exposure of Haul Truck Drivers at a Surface Coal Mine. Applied Ergonomics, 45, (6); (2014), 1700 - 1704.

[4] United States Bureau of Labor and Statistics (2015). Non-Fatal Occupational Injuries and Illnesses Requiring Days Away from Work. https://www.bls.gov/news.release/osh2.toc.html. Accessed on April 22, 2020.

[5] X. Zhao, C. Schindler. Evaluation of Whole Body Vibration Exposure Experienced by Operators of a Compact Wheel Loader According to ISO 26311:1997 and ISO 2631-5:2004. International Journal of Industrial Ergonomics, 44, (6); (2014), 840 - 850.

[6] K.A. Zinck. The Evaluation of Human Vibration Measurements and the Effectiveness of Different Vibration Reduction Strategies in a Sawmill. Being a Conference Paper Presented at the Worker's Compensation Board, United Kingdom, (2000), 9 - 12.

[7] O.A. Orelaja, X. Wang, D.S. Ibrahim, U. Sharif, U. Evaluation of Health Risk Level of HandArm and Whole-Body Vibrations on the Technical Operators and Equipment in a TobaccoProducing Company in Nigeria. Journal of Healthcare Engineering, (2019), 20 - 31.

[8] H.S. Seidel. Selected Health Risks Caused by Long-Term, Whole-Body Vibration. American Journal of Industrial Medicine, (23); (1993), 589 - 604.

[9] M.A. Bovenzi, A.C. Zadini, A.O. Franzinelli, F.M. Borgogni. Occupational Musculoskeletal Disorders in the Neck and Upper Limbs of Forestry Workers Exposed to Hand-arm Vibration. International Journal of Health and Ergonomics, (34), (1991), 547 - 562.

[10] N.J. Mansfield. Human Response to Vibration. New York, CRC Press, Boca Raton, FL, USA, (28); (2004), 23 - 32.

[11] European Union Parliament. Directive 98/37/EC of the European Parliament Council on the Approximation of the Laws of the Member States Relating to Machinery. OJL 207, (1998), 64 -75 .

[12] International Organization for Standardization (ISO). Mechanical Vibration and Shock Evaluation of Human Exposure to Whole-body Vibration-part 1. International Organization for Standardization. (1997), ISO 2631-1.

[13] D.G. Wilder. The Biomechanics of Vibration and Low Back Pain. American Journal of Industrial Medicine, (23); (1993), 577 - 588. 
[14] Federal Environmental protection Agency (FEPA). Interim Guidelines and Standards for Industrial Effluents, Gaseous Emissions, and Hazardous Wastes in Nigeria. Federal Environmental Protection Agency. (1991), 52 - 53.

[15] Environmental Protection Authority. Wood Processing Works. Environmental Protection Authority. (2002), Available online: http//::www.epa.org. Accessed on March 31, 2020.

[16] L.G. Punnett, J.S. Park, L. Punnett. Work Routinization and Implications for Ergonomic Exposure Assessment. Ergonomics, 49, (1); (2006), 12 - 27.

[17] International Organization for Standardization (ISO). Mechanical Vibration and Shock Evaluation of Human Exposure to Whole-Body Vibration. Part 5: Method for Vibration Containing Multiple Shocks. International Organization for Standardization, Geneva, Switzerland, (2004), 2631 - 2635.

[18] H. Jahncke, S. Hygge, S.E. Mathiassen, D. Hallman, S. Mixter, E. Lyskov. Variation at Work: Alternations between Physically and Mentally Demanding Tasks in Blue-Collar Occupations. Ergonomics, 60, (9); (2017), 1218 - 1227.

[19] Health and Safety Executives (HSE) (2005).Hand-arm vibration exposure calculator, available online: http://www.hse.gov.uk/vibration/hav.xls.

[20] Health and Safety Executive (HSE) (2019) Vibration: Employers' responsibilities-legal duties; Vibration Levels.

https://www.hse.gov.uk/vibration/hav/advicetoemployers/responsibilities.htm 